\section{Brazilian Journal \\ of Chemical \\ Engineering}

ISSN 0104-6632

Printed in Brazil www.scielo.br/bjce

Vol. 35, No. 01, pp. 91 - 100, January - March, 2018

(cc) BY

dx.doi.org/10.1590/0104-6632.20180351s20160599

\title{
APPLICATION OF SUBMERGED MEMBRANE BIOREACTOR TECHNOLOGY FOR THE TREATMENT OF HIGH STRENGTH DAIRY WASTEWATER
}

\author{
Hanife Sari Erkan ${ }^{1 *}$, Gorkem Gunalp ${ }^{1}$ and Guleda Onkal Engin ${ }^{1}$ \\ ${ }^{1}$ Yildiz Technical University, Faculty of Civil Engineering, Department of Environmental Engineering, 34220 \\ Davutpasa, Esenler, Istanbul, Turkey. E-mail: hsari@yildiz.edu.tr; gorkem_gunalp@hotmail.com; gengin@yildiz.edu.tr
}

(Submitted: October 21, 2016; Revised: November 29, 2016; Accepted: December 8, 2016)

\begin{abstract}
In this study, an aerobic submerged membrane bioreactor (sMBR) was used for the treatment of dairy wastewater at $15 \mathrm{~h}$ of hydraulic retention time (HRT) and $40 \mathrm{~d}$ of sludge retention time (SRT) with constant permeate flux $\left(9.5 \mathrm{~L} \cdot \mathrm{m}^{-3} \cdot \mathrm{d}^{-1}(\mathrm{LMH})\right)$. The COD, ammonia-nitrogen $\left(\mathrm{NH}_{3}-\mathrm{N}\right)$ and orthophosphate $\left(\mathrm{PO}_{4}-\mathrm{P}\right)$ removal efficiencies were $98.2 \%, 95.4 \%$ and $88.9 \%$, respectively. The results demonstrated that sMBR was a suitable and effective treatment for removal of organic matter and nutrients for treating dairy wastewater. The properties of the activated sludge, such as extracellular polymeric substances (EPS) and soluble microbial products (SMP) concentration, protein and carbohydrate, relative hydrophobicity, zeta potential and floc size distribution were also investigated. According to the results obtained, the total EPS content was lower than that of domestic wastewater treatment by MBR technology.
\end{abstract}

Keywords: Activated sludge; dairy industry wastewater; extracellular polymeric substances; membrane bioreactors

\section{INTRODUCTION}

Among the food industries, the dairy industry is generally considered to be the largest source of pollution (Farizoglu and Uzuner, 2011; Andrade et al., 2013). Since water is used in almost all steps of dairy production industry, such as heating, sanitization, cooling, and cleaning, high amounts of wastewater are generated (Sarkar et al., 2006; Chen and Liu, 2012). It was reported that the dairy industry produces on an average $2.5-3.0$ liters of wastewater per liter of milk processed (Singh et al., 2014). The effluents of this industry are generally characterized by high organic matter and nutrients, mainly proteins, carbohydrates, and fats originated from milk, and residual cleaning agents (Perle et al., 1995; Andrade et al., 2013). Significant variations in COD (430-18,045 $\mathrm{mg} / \mathrm{L})$ and BOD (40-8,240 $\mathrm{mg} / \mathrm{L})$ have been reported by researchers for the dairy industry wastewater (Koyuncu et al., 2000; Schwarzenbeck et al., 2005; Passeggi et al., 2009). The reason for COD variations is primarily affected by the milk, whey, or cream (Kushwaha et al., 2011). It was reported that the $\mathrm{pH}$ varies between 4.7 to 11 (Passeggi et al., 2009), while the suspended solids (SS) concentration varies between 0.024 to $4.5 \mathrm{~g} / \mathrm{l}$ (Kushwaha et al., 2011). Significant amount of nutrients can also be found, for example $14-830 \mathrm{mg} / \mathrm{L}$ of total nitrogen (TN) (Rico Gutierrez et al., 1991) and 9-280 mg/L of total phosphorus (TP) (Gavala et al., 1999). Small quantities of detergents and their additives are also present. These additives can be acidic or alkaline, and typically include additives, such as phosphates, surfactants, and sequestering agents 
(Grasshoff, 1997). Dairy wastewater always includes micronutrients such as $\mathrm{Na}, \mathrm{Cl}, \mathrm{K}, \mathrm{Ca}, \mathrm{Mg}, \mathrm{Fe}, \mathrm{Co}, \mathrm{Ni}, \mathrm{Mn}$. The presence of high $\mathrm{Na}$ and $\mathrm{Cl}$ concentration is due to the use of large quantities of alkaline cleaners in the plant (Demirel et al., 2005).

Commonly, conventional treatment processes, such as primary treatment and biological treatment, have been used for dairy wastewater treatment, though each of these systems has some disadvantages, such as high energy requirement, high scum production, low settleability of sludge, low resistance to shock loadings, difficulties in nutrients removal (Chen and Liu, 2012; Andrade et al., 2013). Also these systems may have some problems in the degradation of fats, oils and other types of specific pollutants (Andrade et al., 2013).

Recently, industries have been searching for new technologies for wastewater treatment, aiming not only at the achievement of standards, but also at acquiring high removal efficiency of the treated effluent for reuse. For these reasons, there is a growing interest in combining membrane systems and biological wastewater processes. The membrane bioreactors (MBR) have distinct advantages over conventional biological processes, such as, higher biodegradation efficiency, smaller footprint, better removal efficiency and treated waste quality, and no settling problems of sludge (Bouhabila and Ren, 2001; Xing et al., 2003; Farizoglu and Uzuner, 2011). Considering these advantages, the MBRs appear to be a promising process for the treatment of dairy industry wastewater.

In spite of the high potential of the MBR applications for dairy wastewater treatment, there are only a few studies conducted using MBR systems (Farizoglu and Uzuner, 2011; Andrade et al., 2013). Some researchers used a membrane sequencing batch reactor (MSBR) for dairy wastewater treatment and obtained high removal efficiencies of COD, nitrogen and phosphorus (Bae et al., 2003; Rezaee et al., 2015). Farizoglu and Uzuner (2011) investigated treatment of dairy industry wastewater in a biological high performance membrane system (aerobic jet loop reactor with ceramic membrane filtration unit). In their study, the organic loading rate was $53 \mathrm{~kg} \mathrm{COD} / \mathrm{m}^{3}$ day and the COD removal efficiency was $97-98 \%$ under 3 hours of hydraulic retention time. Chen and Liu (2012) studied dairy wastewater treatment with coagulation and a MBR hybrid system. The MBR capacity was $7 \mathrm{~L} / \mathrm{h}$ and the HRT was controlled at $10 \mathrm{~h}$. It was reported that the hybrid system reduced $98 \% \mathrm{COD}$ and, as a result, the effluent COD value decreased to $8 \mathrm{mg} / \mathrm{L}$. The authors remarked that the combination of coagulation with MBR presents the possibility and applicability to reclaim effluent in dairy industries. Praneeth et al. (2014) investigated the performance of sMBR in treating dairy wastewater using a laboratory-scale HRT of 10 hours. The removal efficiencies were over $91 \%$ and $86 \%$ for COD and BOD, respectively. Andrade et al. (2013) investigated real dairy industry wastewater treatment with aerobic MBR. The 6 and 8 hours of HRT were studied and, for both HRT values, the organic matter removal efficiencies were found to be $99 \%$.

The aim of this study is to evaluate the performance of the sMBR in the treatment of pre-treated dairy industry wastewater. Another important point determined was that activated sludge treating industrial wastewater exhibited different properties compared to activated sludge treating domestic wastewater. Therefore, the study also focused on physico-chemical properties of the activated sludge, such as EPS, SMP, protein and carbohydrate, relative hydrophobicity.

\section{MATERIALS AND METHODS}

\section{Characterization of wastewater and inoculum}

The dairy wastewater was taken from the wastewater treatment plant of a dairy factory in Istanbul. During the experimental period, approximately 1000 L of dairy wastewater was obtained from the factory at two different times and was stored at $4{ }^{\circ} \mathrm{C}$ to prevent degradation.

Milk, yogurt and butter are the main products of the factory. The dairy wastewater was treated using the combination of chemical coagulation with ferric chloride and aerobic activated sludge process on the premises of the plant. The chemical coagulation was performed in the plant in order to remove total suspended solids (TSS). The characteristics of raw wastewater and the effluent of the chemical coagulation process are shown in Table 1. The effluent wastewater from chemical coagulation was used to feed the sMBR. The $\mathrm{C} / \mathrm{N} / \mathrm{P}$ ratio of the pre-treated wastewater was found to be around 100/1.5/0.12. In order to provide the $100 / 5 / 1$ ratio for aerobic biological treatment criteria, the required amounts of urea and orthophosphoric acid were added to pre-treated wastewater.

The activated sludge used in the sMBR was obtained from a municipal wastewater treatment plant in Istanbul. The concentrations of MLSS and MLVSS of the activated sludge were $7.9 \mathrm{~g} / \mathrm{L}$ and $5.15 \mathrm{~g} / \mathrm{L}$, respectively.

A schematic plan of the sMBR system can be seen in Figure 1. The sMBR had $10 \mathrm{~L}$ effective volume. As mentioned previously, the SMBR was fed with pre-treated dairy industry wastewater obtained from the effluent of chemical coagulation and operated for a period of 100 days. A hollow fibre membrane module $(0.4 \mu \mathrm{m}$ pore size $)$ with a total effective area of $0.07 \mathrm{~m}^{2}$ was used in the sMBR. Filtration was operated continuously from the sMBR by imposing a negative pressure on the fibres. The sMBR was monitored using an automation system provided by HAMLE Engineering Automation Limited Company. The detailed information on the system is provided in our previous study (Sari Erkan et al., 2016). 
Table 1. Characteristics of raw and pre-treated dairy wastewater

\begin{tabular}{lccc}
\hline Parameter & Unit & Raw wastewater & Pre-treated wastewater \\
\hline $\mathrm{COD}$ & $\mathrm{mg} / \mathrm{L}$ & $7136 \pm 75$ & $6404 \pm 46$ \\
$\mathrm{BOD}_{5}$ & $\mathrm{mg} / \mathrm{L}$ & $4900 \pm 37$ & $4418 \pm 25$ \\
$\mathrm{TS}$ & $\mathrm{mg} / \mathrm{L}$ & $12120 \pm 280$ & $11410 \pm 150$ \\
$\mathrm{TSS}$ & $\mathrm{mg} / \mathrm{L}$ & $1820 \pm 130$ & $214 \pm 15$ \\
$\mathrm{TKN}$ & $\mathrm{mg} / \mathrm{L}$ & $95 \pm 7.30$ & $94 \pm 9$ \\
$\mathrm{NH}_{3}-\mathrm{N}$ & $\mathrm{mg} / \mathrm{L}$ & $30 \pm 2$ & $28 \pm 4$ \\
$\mathrm{NO}_{3}-\mathrm{N}$ & $\mathrm{mg} / \mathrm{L}$ & $3.2 \pm 0.8$ & $3.2 \pm 0.35$ \\
$\mathrm{TP}$ & $\mathrm{mg} / \mathrm{L}$ & $8.0 \pm 0.55$ & $7.9 \pm 1.5$ \\
$\mathrm{PO}_{4}-\mathrm{P}$ & $\mathrm{mg} / \mathrm{L}$ & $3.29 \pm 0.35$ & $2.77 \pm 0.25$ \\
$\mathrm{pH}$ & - & $5.59 \pm 0.1$ & $5.41 \pm 0.2$ \\
$\mathrm{Conductivity}$ & $6.15 \pm 0.64$ & $6.08 \pm 0.03$ \\
Alkalinity & $\mathrm{mS} / \mathrm{cm}\left(20^{\circ} \mathrm{C}\right)$ & $1225 \pm 35$ & $181.6 \pm 25$ \\
Chloride & $\mathrm{mg} \mathrm{CaCO} / \mathrm{L}$ & $1728 \pm 146$ & $1682 \pm 150$ \\
\hline
\end{tabular}

\section{System used and operating conditions}

The operating conditions are presented in Table 2. As can be seen from Table 2, the F/M ratio was $0.2 \mathrm{kgCOD} /$ kgMLSS.day in the sMBR at steady-state conditions. According to Judd (2006), the majority of MBRs operate with lower F/M ( $<0.25 \mathrm{kgCOD} / \mathrm{kgMLSS}$.day $)$ for treating industrial effluents.

The sMBR system was operated under $7.5 \mathrm{~kg} / \mathrm{m}^{3}$.day of organic loading rate and at SRT of 40 days at steady-state conditions. The sMBR was continuously fed on pre-treated dairy industry wastewater which is located in the Istanbul region.

\section{Sampling and analyses}

The measurements of COD, TKN, ammonia nitrogen $\left(\mathrm{NH}_{3}-\mathrm{N}\right)$, and orthophosphate $\left(\mathrm{PO}_{4}-\mathrm{P}\right)$ in the feed wastewater and the permeate, MLSS and MLVSS in the sMBR were carried out according to the Standard Methods (2005). DO and $\mathrm{pH}$ measurements were conducted daily, while $\mathrm{COD}, \mathrm{NH}_{3}-\mathrm{N}$, and $\mathrm{PO}_{4}-\mathrm{P}$ analyses were performed every other day. For the determination of activated sludge properties in the sMBR, the analyses of EPS, SMP, carbohydrate, protein, hydrophobicity and critical flux were conducted once every 15 days. In order to see the repeatability of the experiments, all the measurements were carried out three times independently.

The analyses of EPS and SMP were carried out by the formaldehyde extraction method (Tinggang et al., 2008). The Lowry method (Lowry et al., 1951) and the phenolsulphuric acid method (Dubois et al., 1956) were used for the analysis of protein and carbohydrate, respectively. The relative hydrophobicity $(\mathrm{RH})$ analyses were conducted by the MATH test (Measuring the Attachment of Bacteria to Hydrocarbons) (Chang and Lee, 1998).

\section{Critical flux and membrane fouling rate determination}

The critical flux analyses were performed by the fluxstep method (Wu et al., 2008). The critical flux of the sMBR was measured using a flat sheet membrane module with an effective filtration area of $0.044 \mathrm{~m}^{2}$. Average pore size of the flat sheet membrane was $0.4 \mu \mathrm{m}$. Fresh flat sheet membranes were used for each critical flux determination. The time intervals were kept constant at 30 minutes for each filtration step.

Membrane fouling rate was determined by short-term filtration experiments which were conducted as by Huang et al. (2000), Liu et al. (2005), and Wu et al. (2007). The same flat sheet membrane module was used for the critical flux determination. The filtration performance of the flat sheet membrane module was carried out with constant flux, by which the critical flux was determined, while the change of TMP was monitored. The degree of membrane fouling was evaluated by the membrane filtration resistance calculated using Eq. 1:

$$
J=\frac{T M P}{\mu R}
$$

where $\mathrm{J}$ is the membrane flux (LMH), TMP is the transmembrane pressure $(\mathrm{Pa}), \boldsymbol{\mu}$ is the water viscosity of the permeate (Pa.s), $\mathrm{R}$ is the resistance of the membrane filtration $(1 / \mathrm{m})$.

The membrane fouling rate $(\Delta R)$ of the mixed liquor was finally calculated as $\Delta R_{30}(1 /(\mathrm{m} \mathrm{h}))$, the change rate of $R$ within 30 min of filtration, according to Eq. 2 .

$$
\Delta R_{30}=\frac{R_{30}-R_{0}}{\Delta t}
$$




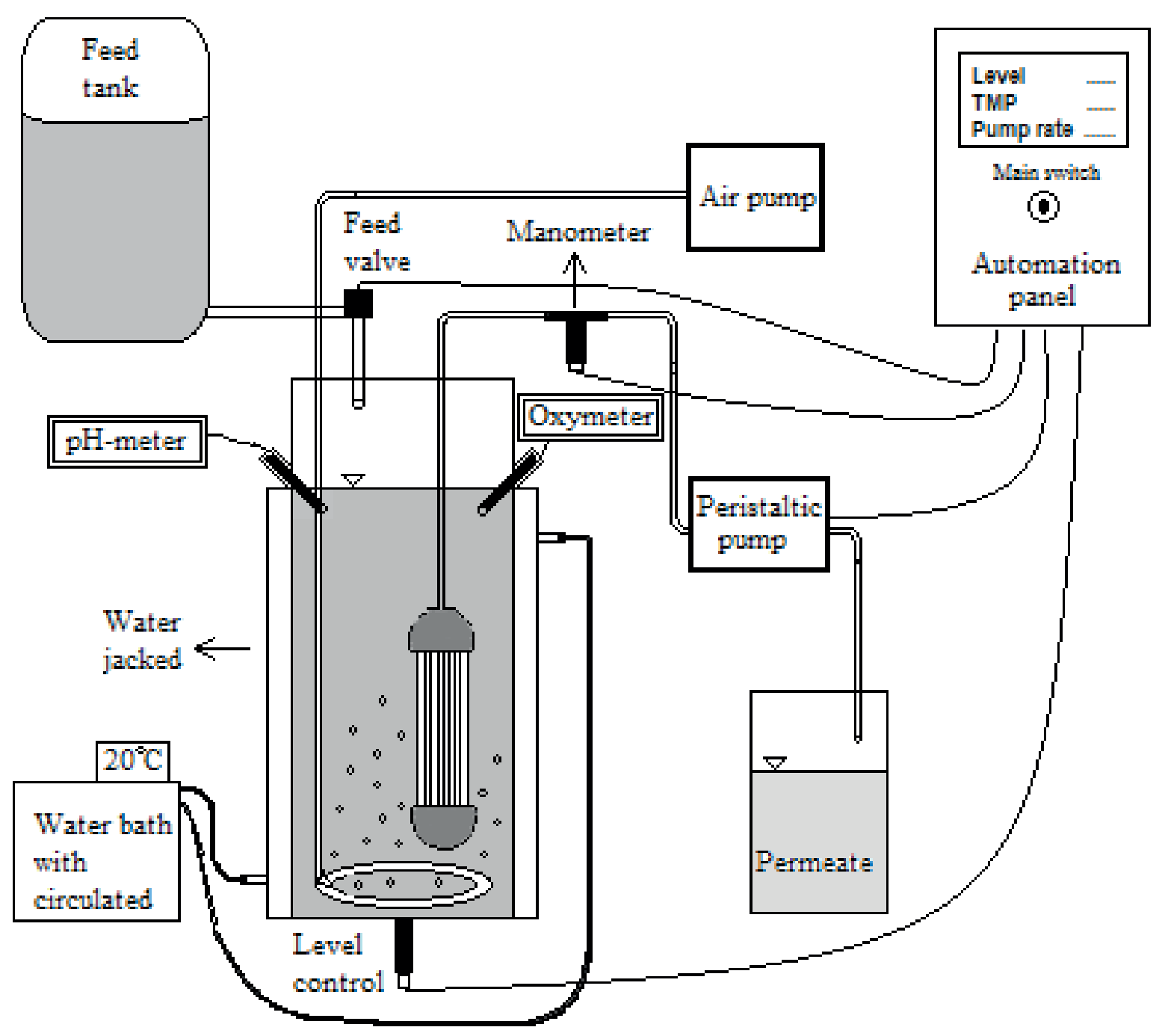

Figure 1. Schematic representation of the submerged membrane bioreactor used.

where $\Delta t$ is the filtration time (h), $R_{0}$ the $R$ value of the module at starting time $(1 / \mathrm{m})$ and $R_{30}$ the $R$ value of the module after 30 min filtration $(1 / \mathrm{m})$.

By combining equation 1 and $2, \Delta R_{30}$ can be rewritten as Eq. 3:

$$
\Delta R_{30}=\frac{T M P_{30}-T M P_{0}}{\mu J \Delta t}
$$

where $\mathrm{TMP}_{0}$ is the TMP value of the module at starting time $(\mathrm{Pa})$ and $\mathrm{TMP}_{30}$ is the TMP value of the module after 30 min filtration $(\mathrm{Pa})$.

The parameters $\mu$ and $J$ in Eq. 3 were adjusted previously to equivalent values at $20^{\circ} \mathrm{C}$ to eliminate the influence of water viscosity variations on filtration resistance.

\section{RESULTS AND DISCUSSION}

\section{Overall performance of the SMBR systems}

During the sMBR operation, the removal efficiencies of $\mathrm{COD}, \mathrm{NH}_{3}-\mathrm{N}$ and $\mathrm{PO}_{4}-\mathrm{P}$ were found to be high. The total removal efficiencies of $\mathrm{COD}, \mathrm{NH}_{3}-\mathrm{N}$ and $\mathrm{PO}_{4}-\mathrm{P}$ were over $98.2 \%, 95.4 \%$ and $88.9 \%$, respectively. The COD removal efficiency indicated that the removal of organic matter was rather successful and nutrient removal efficiencies showed $\mathrm{NH}_{3}-\mathrm{N}$ and $\mathrm{PO}_{4}-\mathrm{P}$ removal was also successful. The sMBR showed high removal efficiencies for organic matter and nutrients. Andrade et al. (2013) investigated dairy wastewater treatment in SMBR at a SRT of 60 days and HRT of 6 and 8 hours, respectively. The authors reported that the organic matter removal efficiencies were over $99 \%$ for both HRTs. Farizoglu et al. (2004) investigated the use 
Table 2. Operating conditions in the sMBR

\begin{tabular}{ll}
\hline Operating Parameter & Value \\
\hline $\mathrm{pH}$ & 8.0 \\
Dissolved oxygen, $\mathrm{mg} / \mathrm{L}$ & $>3.0$ \\
Temperature, ${ }^{\circ} \mathrm{C}$ & 21 \\
$\mathrm{HRT}$, hours & 15 \\
$\mathrm{SRT}$, days & 40 \\
$\mathrm{~L}_{\text {org }}, \mathrm{kg} \mathrm{COD} / \mathrm{m}^{3} . \mathrm{day}$ & 7.5 \\
$\mathrm{~F} / \mathrm{M}$ ratio, $\mathrm{kg} \mathrm{COD} / \mathrm{kg}$ MLSS.day & 0.2 \\
Membrane flux, $\mathrm{L} / \mathrm{m}^{2} \cdot \mathrm{h}$ & 9.5 \\
\hline
\end{tabular}

of an aerobic jet loop bioreactor coupled to membranes for the treatment of whey from a cheese-making process. The authors achieved COD removal efficiencies over 94\%; however, the HRT and SRT were 0.82 to 2.8 days and 1.1 to 2.8 days, respectively. On the other hand, it is known that application of high SRTs in sMBRs contribute to nitrification in these systems. Thus, nitrifying bacteria, which are notoriously slow growing microorganisms, are responsible for the conversion of ammonia nitrogen into nitrate (Judd, 2006). Andrade et al. (2013) reported that $\mathrm{NH}_{3}-\mathrm{N}$ and TN removal efficiencies were $96 \%$ and $98 \%$, when the dairy wastewater was treated in the sMBR at 8 $\mathrm{h}$ of HRT. It was stated in an earlier study that significant removal of TN is not expected, once the reactor is operated under fully aerated conditions (Puznava et al., 2001). However, it is known that, due to lack of oxygen, anoxic zones can form in the inner regions of the activated sludge flocs, thereby providing convenient conditions for denitrification (Puznava et al., 2001). Otherwise, some researchers had high phosphorus removal efficiencies in MBR systems when they were treating dairy industry wastewater (between 53-85\%) (Farizoglu et al., 2007; Andrade et al., 2013). According to the researchers, these high removal efficiencies were due to a considerable uptake of phosphorus for new microorganism synthesis, since the MLSS concentration was high in the reactor, and to phosphate precipitation with $\mathrm{Ca}^{2+}$ and $\mathrm{Na}^{+}$ions. Both reasons account for high phosphorus removal efficiencies in this study.

\section{Variations of biomass, SMP and EPS in SMBR}

Concentrations of MLSS and MLVSS during the operation of the sMBR are shown in Figure 2-a. The initial concentrations of MLSS and MLVSS were around 2480 $\mathrm{mg} / \mathrm{L}$ and $1740 \mathrm{mg} / \mathrm{L}$, respectively, corresponding to a MLVSS/MLSS ratio of $70 \%$. Throughout the operation of 100 days, the concentrations of MLSS and MLVSS increased slightly and they reached $34,070 \mathrm{mg} / \mathrm{L}$ and $29,130 \mathrm{mg} / \mathrm{L}$ at the end of the operation, respectively, corresponding to a MLVSS/MLSS ratio of around $85.5 \%$, showing the activity of the inoculum. $400 \mathrm{~mL}$ of biomass was drawn daily from the sMBR in order to keep the SRT value at $40 \mathrm{~d}$, both MLSS and MLVSS concentrations remained almost constant after the sMBR reached steadystate condition (after 37 days). It was reported that the SRT in aerobic MBRs should be controlled between 20 and 50 days in order to control the concentration of EPS and the membrane fouling (Meng et al., 2009). Therefore, in this study, the SRT was kept at 40 days during the sMBR operation.

Bound or soluble forms of extracellular polymeric substances are considered as the predominant component causing membrane fouling in MBRs (Meng et al., 2009). Bound EPS is composed of carbohydrates, proteins, nucleic acids, lipids, and humic acids. Soluble EPS or SMP can be defined as the pool of organic compounds which are excreted into solution from the microorganism (Meng et al., 2009). As the carbohydrate and protein are regarded as the major components (Meng et al. 2006), these are considered to represent the total amount of EPS and SMP in this study. The experimental results of EPS and soluble EPS (SMP) are presented in Figure 2-b. In the sMBR, the EPS concentration decreased steadily throughout the reactor operation and the EPS reached constant values when the sMBR reached the steady-state condition. The EPS $_{c}$ (carbohydrate fractions of EPS) and EPS (protein fractions of EPS) concentrations in the SMBR averaged 5.6 $\pm 0.4 \mathrm{mg} / \mathrm{g}$ MLSS and $10.0 \pm 0.25 \mathrm{mg} / \mathrm{g}$ MLSS, respectively. Total EPS of activated sludge in MBRs generally fall in the range of $20-250 \mathrm{mg} / \mathrm{g}$ MLSS, in the case of domestic wastewater treatment (Lee et al. 2003; Meng et. al. 2007; Lin et al. 2014). Masse et al. (2006) reported that the total EPS content was $20-40 \mathrm{mg} / \mathrm{g}$ MLVSS at 53 days of SRT. In this study, the total EPS content was found to be $15.6 \pm$ $0.65 \mathrm{mg} / \mathrm{g}$ MLSS, slightly lower than those reported in the literature.

The carbohydrate and protein concentrations of SMP $\left(\mathrm{SMP}_{\mathrm{c}}\right.$ and $\left.\mathrm{SMP}_{\mathrm{p}}\right)$ in the supernatant and permeate of the sMBR are shown in Figure 2-c. The total concentrations of SMP in the supernatant and the permeate of SMBR averaged $70.85 \pm 4.73 \mathrm{mg} / \mathrm{L}$ and $34.08 \pm 0.70 \mathrm{mg} / \mathrm{L}$, respectively, corresponding to around $46.6 \%$ SMP rejection by the membrane. In the sMBR, the supernatant and permeate concentrations of SMP were $28.27 \pm 2.12$ $\mathrm{mg} / \mathrm{L}$ and $4.10 \pm 0.61 \mathrm{mg} / \mathrm{L}$, respectively, corresponding to around $85 \%$ rejection by the membrane. On the other hand, the supernatant and permeate concentrations of $\mathrm{SMP}_{\mathrm{p}}$ were $42.57 \pm 3.36 \mathrm{mg} / \mathrm{L}$ and $30.0 \pm 1.23 \mathrm{mg} / \mathrm{L}$, respectively, corresponding to around $30 \%$ rejection by the membrane. As a conclusion, much higher SMP rejection performance $(85 \%)$ was achieved compared to $\operatorname{SMP}_{\mathrm{p}}(30 \%)$. The reason for this could be due to different molecular weights of the $\mathrm{SMP}_{\mathrm{c}}$ and $\mathrm{SMP}_{\mathrm{p}}$ produced. It was reported by $\mathrm{Ng}$ et al. (2006) that carbohydrate and protein have different transmembrane rates throughout the membrane, so different rejection performances can be obtained for the rejection of $\mathrm{SMP}_{\mathrm{c}}$ and $\mathrm{SMP}_{\mathrm{p}}$. 


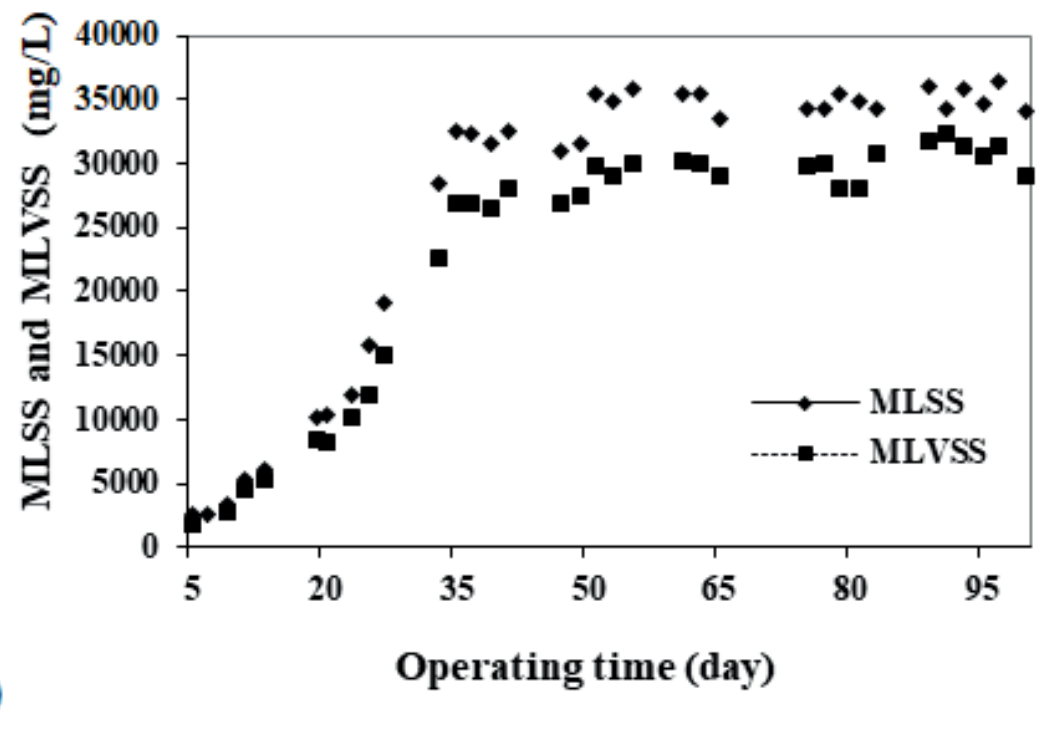

(a)

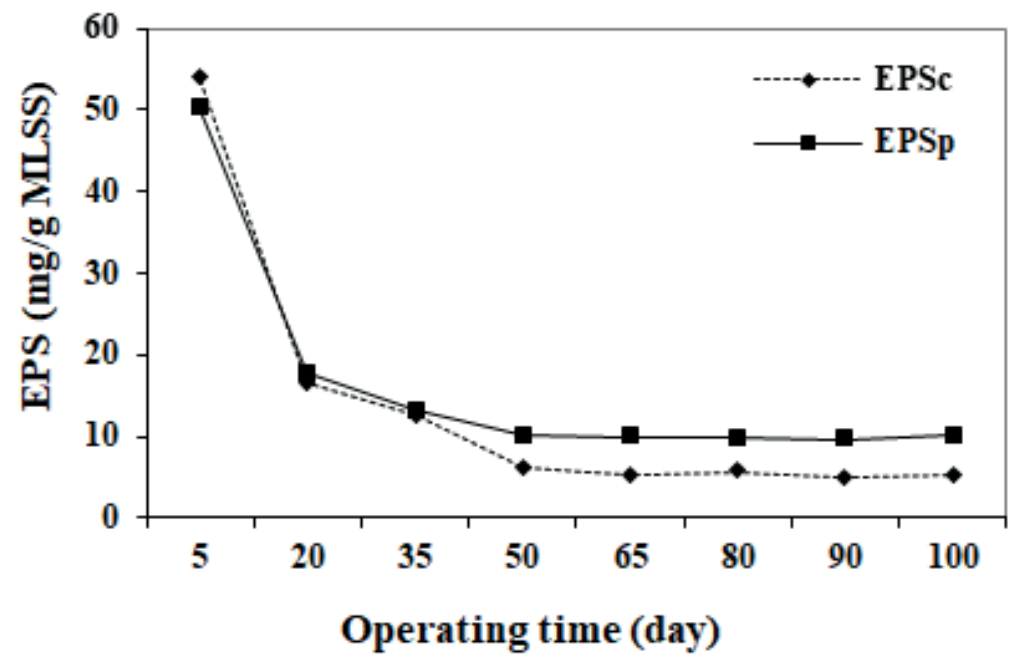

(b)

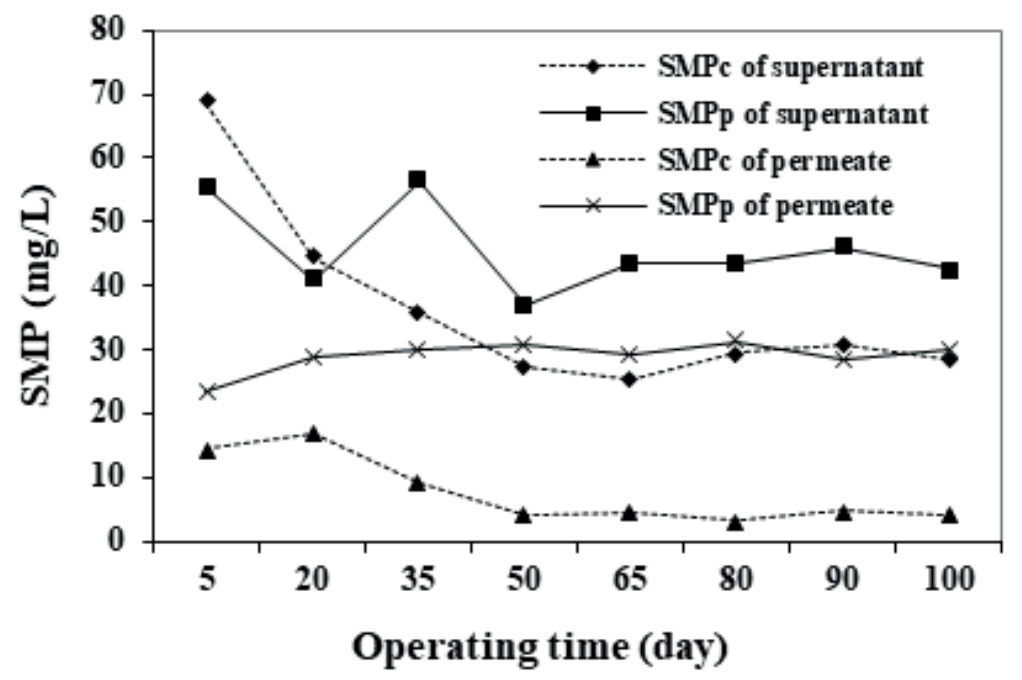

(c)

Figure 2. Concentrations of MLSS, MLVSS (a), SMP (b) and EPS (c) 


\section{Membrane filtration performance and critical flux analyses in the sMBR system}

Figure 3 shows the flux and transmembrane pressure (TMP) of the sMBR. Dotted lines mark the operation days when physical cleaning with tap water and a sponge cleaner was carried out. During the operations, the permeate flux was around 9.5 LMH. Maximum fluxes acquired in sMBR for domestic wastewater were usually between 25 and 30 $\mathrm{LMH}$; however, for industrial wastewater these values were found to be between 5 and $15 \mathrm{LMH}$ (Cornel and Krause, 2008). The TMP values increased sharply just after the system's initiation and the TMP values reached approximately 378 mbars. On day 13, the first physical cleaning was applied using a sponge cleaner. After physical cleaning, the TMP value remained below 260 mbars for around 30 days and increased steadily. On day 45, 55, 67, 79 and 95 , the recovery of flux was attained by physical cleaning.

The critical flux measurements were conducted two times: on days 40, and 80 when the sMBR reached the steady-state condition. The average critical flux values did not change significantly on different operating days and averaged between 12-14 LMH. Therefore, the sMBR was operated under sub-critical flux conditions during the study. Many industrial MBR systems were operated at low membrane flux (Wang et al., 2005; Hoinkis and Panten 2008). Membrane fouling rate determination was conducted at constant membrane flux $(9.5 \mathrm{LMH})$ when the sMBR reached the steady-state condition. In this study, $\Delta \mathrm{R}_{30}$ was found as $4.11 \times 10^{13} \mathrm{1} / \mathrm{m} . \mathrm{h}$.

\section{Relative Hydrophobicity of activated sludge}

Bacterial floc hydrophobicity (relative hydrophobicity:
$\mathrm{RH}$ ) is the tendency of flocs to repel water. Van Loosdrecht et al. (1987) reported that the attachment of sludge flocs would increase as RH increased. On the other hand, it was reported that the EPS had a strong positive influence on the RH of activated sludge, however EPS had no significant influence (Jorrand et al. 1998; Lee et al. 2003). Therefore, increased hydrophobicity of EPS is more likely to enhance attachment of flocs on the membrane surface than hydrophobic EPS. The relationship between relative hydrophobicity and protein/carbohydrate $(\mathrm{P} / \mathrm{C})$ ratio of EPS of the activated sludge was seen in Figure 4. It can be stated that there is a positive linear correlation between them with a correlation coefficient $\left(\mathrm{R}^{2}\right)$ of 0.834 after 35 days of operation (Figure 5). Joglekar and May (1987) suggested that $\mathrm{R}^{2}$ should be at least 0.80 for a good fit of a model. As known in the literature, mainly amino acids with hydrophobic side groups contribute significantly to the hydrophobicity of the microbial surface. Therefore, the relative hydrophobicity increased with increasing $\mathrm{P} / \mathrm{C}$ ratio of EPS.

\section{CONCLUSIONS}

Taking into consideration the complexity and high strength of dairy wastewaters, it is very important that dairy product manufacturers need to utilize effective treatment technologies before discharging effluents to the environment. Most of the time, conventional treatment systems are not cost effective and these systems may produce high amounts of excess sludge.

To address these problems and to find out sound solutions for the manufacturers, the treatment of dairy industry wastewater was studied using an aerobic submerged MBR operated at $40 \mathrm{~d}$ of SRT and $15 \mathrm{~h}$ of HRT.

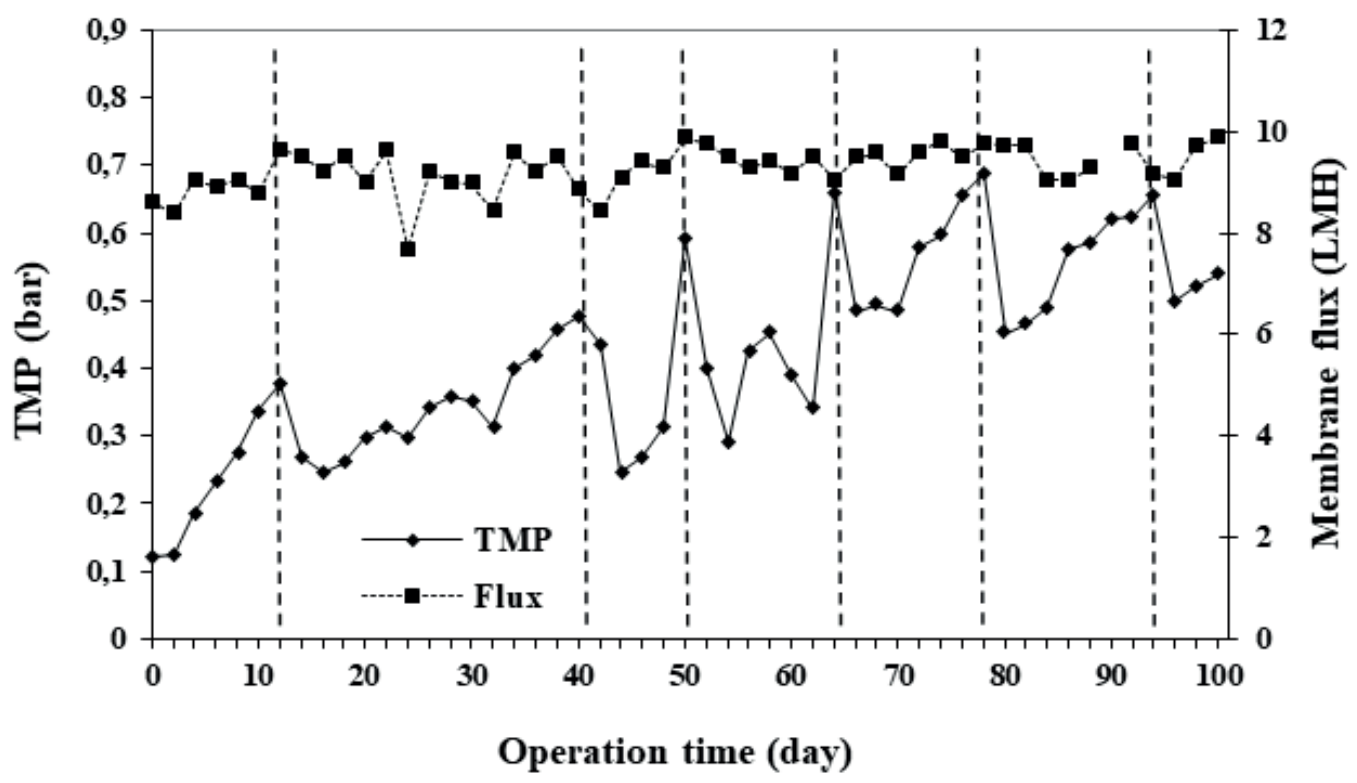

Figure 3. TMP and flux values of sMBR systems 


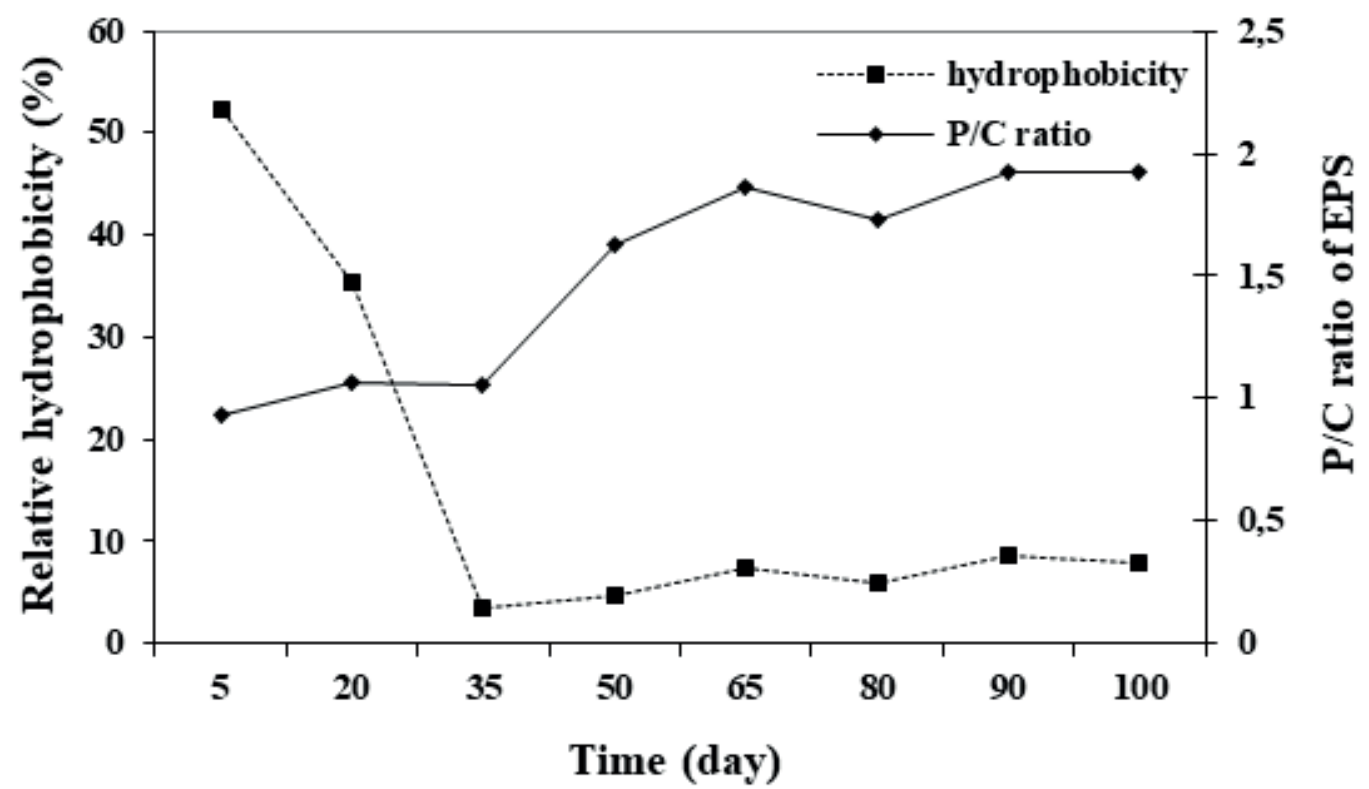

Figure 4. Variation of activated sludge relative hydrophobicity and protein/carbohydrate ratio $(\mathrm{P} / \mathrm{C})$ of EPS.

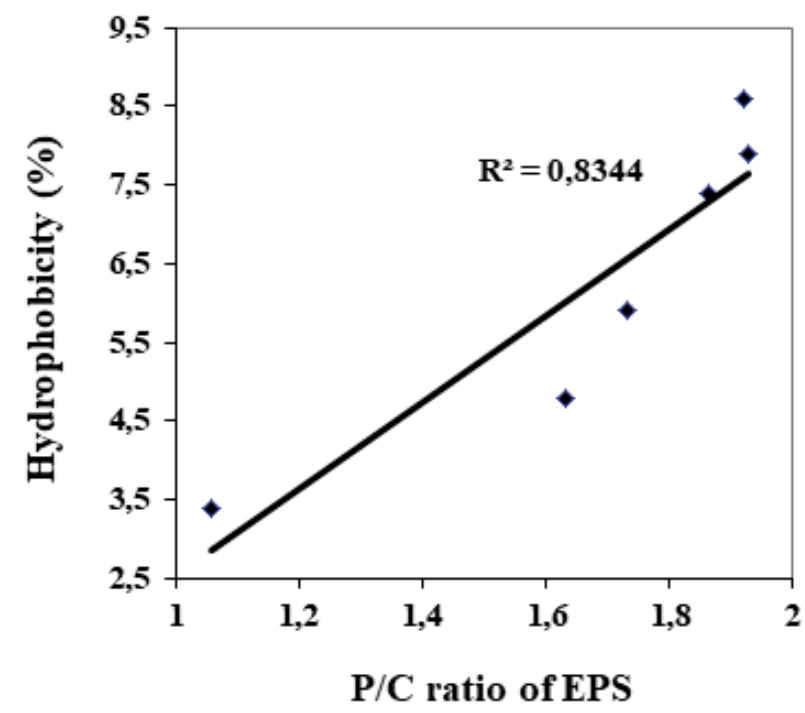

Figure 5. Relationship between relative hydrophobicity and $\mathrm{P} / \mathrm{C}$ ratio of EPS after 35 days of MBR operation.

The sMBR produced an effluent COD value of $115.3 \pm 25$ $\mathrm{mg} / \mathrm{L}$. It was found that operation of the sMBR at 9.5 LMH was sustainable with regular maintenance. The results indicated that low EPS was produced and especially SMP rejection by the membrane was quite high. On the other hand, a linear correlation was found between the relative hydrophobicity and $\mathrm{P} / \mathrm{C}$ ratio of EPS of the activated sludge. According to the results obtained, dairy industry wastewater discharge limits (direct discharge to a receiving water body) have been met based on the standards in Water Pollution Control Regulation of Turkey (COD $<160 \mathrm{mg} / \mathrm{L}$ ) (Ministry of Environment and Urbanization, MoEU).

\section{ACKNOWLEDGEMENTS}

The authors would like to thank the Scientific and Technological Research Council of Turkey (TUBITAK) for financially supporting this study under the project no. 112Y308.

\section{REFERENCES}

Andrade, L.H., Motta, G.E. and Amaral, C.S., Treatment of dairy wastewater with a membrane bioreactor, Brazilian Journal Of Chemical Engineering, 30, No. 04, 759 (2013).

Bae, T.H., Han, S.S. and Tak, T.M., Membrane sequencing batch reactor system for the treatment of dairy industry wastewater, Process Biochemistry, 39, 221 (2003).

Bouhabila, E. and Ben, R. Aim and Buisson Fouling characterization in membrane bioreactors, Separation and Purification Technology, 22-23, 123 (2001).

Chang, I.S. and Lee, C.H., Membrane filtration characteristics in membrane-coupled activated sludge system - the effect of physiological states of activated sludge on membrane fouling, Desalination, 120, 221 (1998).

Chen, W. and Liu, J., The possibility and applicability of coagulation-MBR hybrid system in reclamation of dairy wastewater, Desalination, 285, 226 (2012).

Cornel, P., Krause, S., Membrane Bioreactors for Wastewater Treatment. In: Li, N.N., Fane, A.G., Ho, W.S.W., Matsuura, T., Advanced Membrane Technology and Applications. John Wiley and Sons: Hoboken, N.J., pp. 217-239 (2008).

Demirel, B., Yenigun, O. and Onay, T.T., Anaerobic treatment of dairy wastewaters: A review, Process Biochemistry, 40, 2583 (2005).

Dubois, M., Gilles, K.A., Hamilton, J.K., Rebers, P.A. and Smith, F., Colorimetric method for determination of sugars and related substances, Analytical Chemistry, 28, 350 (1956). 
Erkan, H.S., Engin, G.O., Ince, M. and Bayramoglu, M.R., Effect of carbon to nitrogen ratio of feed wastewater and sludge retention time on activated sludge in a submerged membrane bioreactor, Environmental Science and Pollution Research, 23, 10742 (2016).

Farizoglu, B. and Uzuner, S., The investigation of dairy industry wastewater treatment in a biological high performance membrane system, Biochemical Engineering Journal, 57, 46 (2011).

Farizoglu, B., Keskinler, B., Yildiz, E. and Nuhoglu A., Cheese whey treatment performance of an aerobic jet loop membrane bioreactor, Process Biochemistry, 39, 2283 (2004).

Farizoglu, B., Keskinler, B., Yildiz, E. and Nuhoglu, A., Simultaneous removal of C, N, P from cheese whey by jet loop membrane bioreactor (JLMBR), Journal of Hazardous Materials, 146, 399 (2007).

Gavala, H.N., Kopsinis, H., Skiadas, I.V., Stamatelatou, K. and Lyberatos, G., Treatment of Dairy Wastewater Using an Upflow Anaerobic Sludge Blanket Reactor, Journal of Agricultural Engineering Research, 73, 59 (1999).

Grasshoff, A., Fouling and cleaning of heat exchanges. In: Bulletin of the IDF, No. 328, IDF, p. 32, Brussels (1997).

Gutierrez, J.L.R., Encina, P.A.G. and Fdz-Polanco, F., Anaerobic treatment of cheese production wastewater using a UASB reactor, Bioresource Technology, 37, 271 (1991).

Hoinkis, J. and Panten, V., Wastewater recycling in laundriesFrom pilot to large-scale plant, Chemical Engineering and Processing: Process Intensification. 47, 1159 (2008).

Huang, X., Liu, R. and Qian, Y., Behaviour of soluble microbial products in a membrane bioreactor, Process Biochemistry, 36, 401 (2000).

Joglekar, A.M. and May, A.T., Product excellence through design of experiments, Foods World, 32, 857-868 (1987).

Jorrand, F., Bigne, F.B., Block, J.C. and Urbain, V., Hydrophobic/ hydrophilic properties of activated sludge exopolymeric substances, Water Science and Technology, 37,307 (1998).

Judd, S., The MBR Book: Principles and Applications of Membrane Bioreactors in Water and Wastewater Treatment. Elsevier Ltd: Oxford (2006).

Koyuncu, I., Turan, M., Topacik, D. and Ates, A., Application of low pressure nanofiltration membranes for the recovery and reuse of dairy industry effluents, Water Science and Technology, 41, 213 (2000).

Kushwaha, J.P., Srivastava, V.C. and Mall, I.D., An Overview of Various Technologies for the Treatment of Dairy Wastewaters, Critical Reviews in Food Science and Nutrition, 51, 442 (2011).

Lee, W., Kang, S. and Shin, H., Sludge characteristics and their contribution to microfiltration in submerged membrane bioreactors, Journal of Membrane Science, 216, 217 (2003).

Lin, H., Zhang, M., Wang, F., Meng, F., Liao, B.-Q., Hong, H., Chen, J. and Gao, W., A critical review of extracellular polymeric substances (EPSs) in membrane bioreactors: Characteristics, roles in membrane fouling and control strategies, Journal of Membrane Science, 460, 110 (2014).

Liu, R., Huang, X., Xi, J.Y. and Qian, Y., Microbial behaviour in a membrane bioreactor with complete sludge retention, Process Biochemistry, 40, 3165 (2005).
Lowry, O.H., Rosebrough, N.J., Farr, A.L. and Randall, R.J., Protein measurement with the folin phenol reagent, Journal of Biological Chemistry, 193, 265 (1951).

Massé, A., Sperandio, M. and Cabassud, C., Comparison of sludge characteristics and performance of a submerged membrane bioreactor and an activated sludge process at high solids retention time, Water Research, 40, 2405 (2006).

Meng, F., Chae, S-R., Drews, A., Kraume, M., Shin, H-S. and Yang, F., Recent advances in membrane bioreactors (MBRs): Membrane fouling and membrane material, review, Water Research, 43, 1489 (2009).

Meng, F., Zhang, H.,Yang, F., Zhang, S., Li, Y. and Zhang, $\mathrm{X}$., Identification of activated sludge properties affecting membrane fouling in submerged membrane bioreactors, Seperation and Purification Technology, 51, 95 (2006).

Meng, F., Shi, B., Yang, F. and Zhang, H., Effect of hydraulic retention time on membrane fouling and biomass characteristics in submerged membrane bioreactors, Bioprocess and Biosystems Engineering, 30, 359 (2007).

Ng, H.Y., Tan, T.W. and Ong, S.L., Membrane fouling of submerged membrane bioreactors: impact of mean cell residence time and the contributing factors, Environmental Science and Technology, 40, 2706 (2006).

Passeggi, M., López, I. and Borzacconi, L., Integrated anaerobic treatment of dairy industrial wastewaterand sludge, Water Science and Technology, 59, 501 (2009).

Perle, M., Kimchie, S. and Shelef, G., Some biochemical aspects of the anaerobic degradation of dairy wastewater, Water Research, 29, 1549 (1995).

Praneeth, K., Moulik, S., Vadthya, P., Bhargavac, S.K., Tardioc, J. and Sridhar, S., Performance assessment and hydrodynamic analysis of a submergedmembrane bioreactor for treating dairy industrial effluent, Journal of Hazardous Materials, 274, 300 (2014).

Puznava, N., Payraudeau, M. and Thornberg, D., Simultaneous nitrification and denitrification in biofilters with real-time aeration control, Water Science and Technology, 43, 269 (2001).

Rezaee, S., Zinatizadeh, A.A.L. and Asadi, A., High rate CNP removal from a milk processing wastewater in a single ultrasound augmented up-flow anaerobic/aerobic/anoxic bioreactor. Ultrasonics Sonochemistry, 23, 289 (2015).

Sarkar, B., Chakrabarti, P.P., Vijaykumar, A. and Kale, V., Wastewater treatment in dairy industries - possibility of reuse, Desalination, 195, 141 (2006).

Schwarzenbeck, N., Borges, J.M. and Wilderer, P.A., Treatment of dairy effluents in an aerobic granular sludge sequencing batch reactor, Applied Microbiology and Biotechnology, 66, 711 (2005).

Singh, N.B., Singh, R. and Imam, M.M., Waste water management in dairy industry: pollution abatement and preventive attitudes, International Journal of Science, Environment and Technology, 3, 672 (2014).

Standard Methods for the Examination of Water and Wastewater 21th edn, American Public Health Association/American Water Works Association/Water Environment Federation, Washington DC, USA (2005). 
Tinggang, L., Renbi, B. and Junxin, L., Distribution and composition of extracellular polymeric substances in membrane-aerated biofilm, Journal of Biotechnololog, 135, 52 (2008).

Van Loosdrecht, M.C., Lyklema, J., Norde, W., Schraa, G. and Zehnder, A.J., The role of bacterial cell wall hydrophobicity in adhesion, Applied and Environmental Microbiology, 53, 81893 (1987).

Wang, Y., Huang, X. and Yuan, Q., Nitrogen and carbon removals from food processing wastewater by an anoxic/aerobic membrane bioreactor, Process Biochemistry, 2005, 40, 1733 (2005).

Water Pollution Control Regulations, Ministry of Environment and Planning, Turkey, 31.12.2004.http://www.mevzuat.gov.tr/
Metin.Aspx? MevzuatKod=7.5.7221\&sourceXmlSearch=\& MevzuatIliski=0 (accessed 05 September 2016).

Wu, Z., Wang, Z., Huang, S., Mai, S., Yang, C., Wang, X. and Zhou, Z., Effects of various factors on critical flux in submerged membrane bioreactors for municipal wastewater treatment, Seperation and Purification Technology, 62, 56 (2008).

Wu, Z., Wang, Z., Zhou, Z., Yu, G. and Gu, G., Sludge rheological and physiological characteristics in a pilot-scale submerged membrane bioreactor, Desalination, 212, 152 (2007).

Xing, X.H., Wen, X.H., Qian, Y., Sun, D., Klose, P.S. and Zhang, $\mathrm{X}$. Q., Fouling and cleaning of microfiltration membrane in municipal wastewater reclamation, Water Science and Technology, 47, 263 (2003). 